Emerald.

\title{
Women's football studies: an integrative review
}

\author{
Maurizio Valenti, Stephen Morrow, and Nicolas Scelles, University of Stirling
}

\begin{abstract}
Purpose of this paper: Women's football has received increasing attention in the academic literature, partly due to its growing popularity worldwide. However, women's football research remains scattered across numerous academic domains. Focusing on the social sciences, humanities and management disciplines, this integrative literature review aims to map and organise contributions, and to identify research directions for future studies within these disciplines.
\end{abstract}

Design/methodology/approach: Using the keywords "women", "girls", "female" and "football” or "soccer" to initially identify articles, an integrative approach was followed to evaluate and analyse relevant literature. 117 academic journals were classified and subsequently divided into 26 themes according to the subject area, topic and level examined.

Findings: Results of this integrative review show an increasing trend of journal publications since 1998, with a large representation of studies related to historical and sociological research, where qualitative methods are dominant. Articles investigating economic, managerial and marketing areas appeared in more recent times. Women's football has been researched from different perspectives (players, fans, sport organisations) and across various countries.

Research limitations/implications: The restricted scope of this review (i.e. its focus on social sciences) and the manual classification of articles represent two limitations of this study. However, the synthesis of academic literature provided may assist scholars who are interested in women's football and women's sports research to fill identified research gaps and contribute to further advance academic investigations in this area.

What is originality/value of paper: This paper provides an overview of salient research avenues and represents the first attempt to critically appraise the direction of academic contributions in women's football for the purpose of advancing scholarly inquiry in this sport.

Keywords: Women's football; women's soccer; sport management; integrative review 
[Type here]

\section{Introduction}

Concomitant with the substantial rise in participation and the increased recognition from international governing bodies (FIFA, 2014, 2016; UEFA, 2016, 2017), women's football has received significant attention from sport academics around the world (Pfister, 2015a). The number of scientific publications has been constantly increasing in the last two decades as researchers have given attention to the development of women's football and its stakeholders. In particular, scholarly inquiry on the women's game has bridged different academic domains (e.g. sport sciences, social sciences, humanities and management) and created interactions between various actors (e.g. players, coaches, fans, the media, policy-makers, football governing bodies) thus contributing to a broader understanding of the directions that this sport has taken over time.

Despite this recent increase in the number of academic publications, only one article (MartinezLagunas, Niessen and Hartmann, 2014) has reviewed women's football literature to date. However, this paper focussed exclusively on studies within sport sciences (e.g. physiological demands and player physical characteristics) while neglecting publications coming from other disciplines. Yet we argue that there is a demonstrable need to extend the review beyond the sport sciences domain as publications in social sciences, humanities and management fields are critical to explain the intricate dynamics surrounding the experiences of women in the game and to describe the multifaceted and arguably challenging context in which women's football operates. 
[Type here]

Therefore, the purpose of the present study is to rigorously review and systematically synthesise research approaches, findings, frameworks and implications of women's football literature in order to:

a) organise women's football literature by categorising published articles;

b) portray a comprehensive panorama of academic research on women's football to date, by highlighting year of publication, publishing outlet, authorship, geographical context and methodological approach; and

c) summarise key findings and suggest research directions for future studies within women's football literature.

\section{Method}

Women's football literature addresses numerous topics and research questions drawing on various academic disciplines, and using different methodologies. Therefore, the approach adopted for this review is based on an integrative methodology which thus permits the combination of different types of research designs, as well as the extraction and synthesis of both qualitative and quantitative data (Whittemore and Knafl, 2005). While integrative reviews are considered inherently complex (Tavares de Souza, Dias da Silva and de Carvalho, 2010) and difficult to implement without a stringent research framework (O’Mathúna, 2000), at the same time they allow for the evaluation of a broad and comprehensive panorama of literature from different disciplines and help shape guidelines for future research (Schulenkorf, Sherry and Rowe, 2016; Torraco, 2005; Whittemore and Knafl, 2005). As suggested by Cooper (1989) and in line with Whittermore and Knafl (2005), a five-step approach was followed in this research: 1) problem identification (already presented in the introduction section), 2) literature search, 3) data evaluation, 4) data analysis, and 5) presentation of findings.

\section{Literature search}


[Type here]

Existing articles represent the data of an integrative review (Torraco, 2005). These were identified following the recommendations outlined by Cooper (1989) who suggested utilising informal, primary and secondary information channels. As search terms, women OR girls OR female, AND football OR soccer were utilised to clearly delineate the starting point of this literature review. No boundaries were defined for publication dates while only full-text English articles were included in the review.

Primary channels of information were accessed through online databases SPORTDiscus and Scopus. The former is a reliable source for sport-specific published articles and was used in previous literature reviews (e.g. Schulenkorf et al., 2016); the latter was chosen due to its broad coverage of social science literature which ensures the capture of relevant material that goes beyond the sport domain such as gender constructions and sexual identities. In addition to the two electronic databases, an "ancestry approach" (Cooper, 1989, p. 43) was employed in an attempt to uncover supplementary sources that meet the inclusion criteria. Secondary information channels such as Google Scholar, Researchgate and Academia were consulted and additional literature was obtained through manual searches of relevant academic journals. Other informal information channels such as conference discussions, grey literature, digital dissertations, conference papers and working papers were also identified.

\section{Data evaluation}

The first part of the evaluation process was accomplished by carefully reading information contained in the article title, abstract and by acknowledging the publication outlet. Published and unpublished studies written in English were included in the review while references were excluded when they fitted in the following categories: book publications, opinion pieces, editorials and newspaper articles. It is important to underline at this stage that papers dealing with women's football from social sciences and management perspectives (e.g. economics, 
[Type here]

history, management, marketing, sociology) were considered for this review, while articles examining women's football with a sport science approach (e.g. physiology, sport medicine, sport psychology) were omitted (see Martinez-Lagunas, Niessen and Hartmann, 2014 for a review of sport sciences literature). It is acknowledged that this represents one of the limitations of this literature review. However, as noted by Torraco (2005) and consistent with Schulenkorf et al. (2016, p. 24), "an integrative review does not presuppose to be exhaustive on any given topic or topics, but rather exhaustive within its predetermined and declared boundaries". The process of literature screening was performed in triangulation (Rothbauer, 2008) between the three authors who eventually agreed to include 117 out of the 138 articles initially examined.

\section{Data analysis}

The process of data analysis was conducted through the review of the full text of each article. These were ordered by: a) year of publication; b) publishing outlet; c) authors' names; d) geographical location where the study was conducted and e) methodological approach and process adopted to analyse data. The data analysis process for the 117 articles continued following Miles and Huberman's (1994) recommendations which suggest dividing data into intellectual bins that ultimately reflect common themes between articles. This categorisation process was conducted by the first author and then discussed with the other authors. It involved identifying the overarching subject area, the specific topics and the principal actors or levels, by examining the articles' publishing outlet, title, keywords and reading the full text with a particular focus on the abstract and main conclusions. When it came to build the final catalogue comprising the relevant literature, information was sorted on a logical sequence of macro- to micro-level around the identified subject areas, topics, actors or levels. An illustration of how this process was performed is presented in Table 1 .

[Table 1 here] 
[Type here]

At this stage, it is important to clarify that while every attempt was made to reach an appropriate categorisation, we acknowledge that the manual classification process remains imperfect and therefore represents a limitation of this study. This is because some topics are easily associable to a particular academic domain, while inevitably others present multi-disciplinary characteristics. For example, research about branding was straightforwardly attributed to a subject area, i.e. marketing, while success, i.e. the study of the socio-economic determinants that lead to international sporting success, has been assigned to economics, although some studies (e.g. Jacobs, 2014) in this category could have also fitted the category of sport management and policy. Thus, we appreciate that research in some areas may overlap. However, we argue that article classification remains part of a fundamental process that helps achieve the first two aims of this integrative literature review.

Once the data analysis was completed, in line with Whittemore and Knalf's (2005) integrative review process, the fifth and final step (i.e. presentation of findings) is described and discussed in the next sections.

\section{Results}

To help reach the first of the proposed objectives for this integrative review, we identified five subject areas, twelve topics and nine actors or levels, which, combined, resulted in 26 unique themes (presented in Table 2). In the next sections, a description of the characteristics that appeared to be relevant to comprehensively paint the current state of the women's football literature will be presented in order to achieve the second aim of this study.

[Table 2 here]

\section{Researched themes and their evolution over time}

Table 3 provides an illustration of articles' distribution over time. 
[Type here]

[Table 3 here]

Early studies on women's football (from 1998 to 2003) focussed exclusively on historical and sociological topics. The historical evolution of the game and players' gender issues are the first two themes to be explored and the first by number of publications (history-evolution-country $=$ $22.2 \%$ of the full sample; sociology-gender-players $=16.2 \%$ ). In 2000, Fasting and Pfister looked at gender issues as experienced by coaches while two years later Christopherson, Janning and McConnel (2002) considered how gender is framed and represented by the media in women's football. In 2003, Knoppers and Anthonissen studied two countries' levels of gender inequality and cultural barriers to understand how these affect participation in the sport.

Over the next six years, from 2004 to 2009 , five new themes started to trigger researchers' interest: the determinants of sporting success in international women's football (e.g. Klein, 2004), the study of female football fandom from a sociological perspective (Kim, 2004) and with an historical approach (Lewis, 2009), the marketing strategic challenges that women's leagues face to sustain their business (Southall, Nagel and LeGrande, 2005) and consumers' attitudes towards attending domestic women's football matches (Klein, 2009).

Articles in the final eight years $(2010-2017)$ almost doubled $(n=76)$ when compared to the output produced between 1998 and $2009(n=41)$. During this last time period, sociological studies remained central with the inclusion of new topics such as migration (e.g. Botelho and Agergaard, 2011) and role models (e.g. Dunn, 2016); and consideration of new actors such as administrators (e.g. Welford, 2011), referees (e.g. Perreau-Niel and Erard, 2015) and female fans (e.g. Pope, 2012). At the same time, experts in sport management started to examine the positions of clubs (Aoki et al., 2010) and the impact of national governing bodies' policies and actions on women's football development (e.g. Kjær and Agergaard, 2013) in order to identify challenges that practitioners were facing in the women's game; studies from sport marketing 
[Type here]

disciplines analysed branding (e.g. Melkersson, 2013) in women's football; while other articles explored aspects related to the attractiveness and competitiveness of women's football (e.g. Hjelm, 2011) as well as the determinants to attend or watch women's football games (e.g. Meier, Konjer and Leinwather, 2016).

Overall, research on women's football can be regarded as a recent area of interest with the first two articles being published as recently as 1998. Discernible peaks in academic publications are noticed in 2003, 2011 and 2013 when the academic journal Soccer \& Society released special issues about the women's game. Notwithstanding the recent drop in 2017, it becomes clear that the attention given to women's football across different academic domains has seen an increase in the last eight years (even when articles in the special issues are excluded).

In sum, women's football literature has seen contributions coming from five areas: economics, history, management, marketing and sociology. Studies related to sociological (48.7\%) and historical (24.8\%) aspects have been published more consistently over time while evidence from marketing $(11.1 \%)$, economic $(11.1 \%)$ and management $(4.3 \%)$ areas emerged more recently. It is also interesting to underline that researchers examined the position of some actors (e.g. players, 22.2\%) and levels (e.g. country-level, 29.9\%) more frequently while other stakeholders (e.g. fans, clubs, federations) started to trigger scholars' curiosity only in recent times.

Table 4 outlines the themes ( 8 out of 26) with more than three publications, representing $75.2 \%$ of the 117 articles selected for this integrative review. This closer inspection of existing articles helps gain a comprehensive understanding of the current state of women's football literature and starts to expose a number of research gaps across different academic domains.

[Table 4 here]

\section{Journals}


[Type here]

Table 5 presents an overview of the first five outlets by number of published articles. The academic journal Soccer \& Society is largely ahead of the other outlets ${ }^{1}$, having published $41.9 \%$ of research articles reviewed here.

[Table 5 here]

\section{Authorship}

There are researchers that contributed to the expansion of women's football literature across different disciplines with five or more articles (as authors or co-authors). Focussing on these authors, it is noticeable that Gertrud Pfister mainly discussed the position of women in society and how they contributed to develop European (German and Danish, in particular) women's football. Also, she helped shape the discussion around gender issues and female fan groups' creation. Overall, her publications account for $9.5 \%$ of research articles included in this review. Kari Fasting (5.5\%) dedicated her studies to the exploration of historical and sociological elements with particular attention given to the experiences of coaches while Stacey Pope (5.2\%) concentrated her works on the examination of female fans' experiences of attending men's and women's football events.

\section{Geographical location of research}

Findings of this integrative review highlight that women's football has been researched worldwide. Specific countries have been studied several times, including European nations (e.g. Denmark, $\mathrm{n}=4$; England, $\mathrm{n}=16$; Germany, $\mathrm{n}=8$; Ireland, $\mathrm{n}=2$; Norway, $\mathrm{n}=7$; Scotland, $\mathrm{n}$ $=3$; Sweden, $\mathrm{n}=3)$, South Korea $(\mathrm{n}=3)$, South Africa $(\mathrm{n}=2)$ and the United States (US) $(\mathrm{n}=$ 12). Also, aspects of women's football have been studied once in other 13 countries (e.g. Australia, Austria, Brazil, Canada, China, France, India, Israel, Italy, Netherlands, New Zealand, Spain and Switzerland). Researchers employed a cross-national approach for precise

\footnotetext{
${ }^{1}$ This is to be expected, given to its specific focus on football (soccer).
} 
[Type here]

macro areas (e.g. Africa $=1$; Europe, $n=6$; Scandinavia, $n=3$; United Kingdom ${ }^{2}, n=11$ ), with a comparative purpose between two or more nations (e.g. Fasting and Pfister, 2000; Knoppers and Anthonissen, 2003) or with a global focus (e.g. Klein, 2004; Torgler, 2008).

In total, there are 11 countries or macro areas where three or more studies were conducted, meaning that $76.7 \%$ of publications are concentrated in these territories. Table 6 shows the distribution of the most researched themes in areas where at least three studies took place.

\section{[Table 6 here]}

Sociological investigations of players' gender issues $(n=16)$ is the leading theme in these countries, followed by historical evolution of the women's game $(n=13)$ and women's football fandom $(n=13)$. Also, women's football was examined from four of the five identified disciplines in England, Europe, Germany and the US while some specific themes were exclusively researched in certain geographical areas (e.g. economic-attractiveness-players was investigated only in Sweden).

\section{Research methodology}

A large majority of studies was conducted using qualitative approaches (Figure 1). Most of the studies dealing with the historical evolution of women's football and articles published in the area of sociology employed document analysis, interviews or mixed methods. All articles in the economics domain used quantitative data and statistical tests such as regression analysis and analysis of variance (ANOVA). Management research combined multiple methods (e.g. combination of observation or questionnaires and interviews) while studies in marketing collected data predominantly via questionnaires and surveys. Studies were labelled as

\footnotetext{
${ }^{2}$ Despite being one political country, United Kingdom presents separate football identities. However, here it was considered as a macro-area due to some studies either including different British nations or not explicitly stating in which part of the United Kingdom the research was conducted.
} 
[Type here]

'conceptual' where no participants were specifically identified but rather a theoretical approach was described.

\section{[Figure 1 here]}

\section{Discussion and conclusions}

The presentation of findings facilitated the fulfilment of the first two aims of this integrative review as it provided a detailed account of women's football literature to date. Building on this newly gained information, the next sections will summarise key findings and suggest future research directions in order to accomplish the third and last objective of this research.

\section{Researched themes and their evolution over time: what's next?}

The presence of some more 'mature' themes (i.e. themes that have been researched more frequently and consistently over time), the emergence of 'recent' research avenues and the overall intensification in the number of publications on women's football indicate that research on this sport is blossoming. In particular, the last two decades have seen studies conducted around 26 different themes. However, the number of themes with less than three publications is 15 , which suggests a need to strengthen and expand the understanding of particular areas, topics and perspectives in women's football research.

As observed in this integrative review, there is an abundance of studies that reported on the stereotypes and continued prejudices present in football (see e.g. Caudwell, 1999, 2003, 2011; Fielding-Loyd and Meân, 2008; Hjelseth and Hovden, 2014). Gender constraints remain a major issue for women to emerge and gain credibility across all levels of the football world, including: coaching (Fasting and Pfister, 2000; Fasting, Sand and Nordstrand, 2017; FieldingLloyd and Meân, 2008; Lewis, Roberts and Andrews, 2015; Norman, 2014; Schlesinger and Weigelt-Schlesinger, 2012; Skogvang and Fasting, 2013), media (Christopherson, Janning and McConnell, 2002; Coche, 2016; Peeters and Elling, 2015; Peeters and van Sterkenburg, 2017; 
Pfister, 2015b; Skogvang, 2009), fandom (Ben-Porat, 2009; Dunn, 2017; Hjelseth and Hovden, 2014; Kim, 2004; Mintert and Pfister, 2015; Pfister, 2013; Pfister, Lennein, Mintert, 2013; Pope, 2012, 2014, 2015, 2016; Pope and Williams, 2011; Selmer and Sülzle, 2010) and refereeing (Kim and Hong, 2016; Perreau-Niel and Erard, 2015), as well as positions of power such as national federations' organisational boards (Strittmatter and Skirstad, 2017; Welford, 2011). The steady number of publications on historical and sociological domains demonstrated that researchers frequently shine a light on the socio-cultural, political, economic and legislative context in which women's football has evolved over time (see e.g. Bourke, 2003; Fasting, 2003; Macbeth, 2002; Pfister et al., 1999). Specifically, the majority of these articles strongly emphasised hegemonic gender relations as part of a dominant logic that still exists across various areas of football. While being predominantly descriptive, these contributions help underline how the history of women's sports (and of women in sport) is deeply characterised by the degree of gender (in)equality and the evolving role of women in society. In line with this, we argue that it remains difficult to discern clearly between football historical accounts and sociological investigations about gender without considering that the game itself represents a platform for the social construction and presentation of hegemonic masculinities (Pfister, 2015a). Thus, we agree with Williams and Hess' (2015) point that any research agenda concerning the relationship between women and football will necessarily contribute to wider understanding of associations between politics, gender and sport. With regards to future studies in these areas, we call for new contributions that specifically look at the experiences of women occupying non-playing roles (e.g. referees) and leadership positions (e.g. administrators, see Burton, 2015 for a review) in (women's) football as comparatively less attention has been paid to the perspective of these actors to date.

Literature considering gender issues further strengthened the conceptualisation that football is male-dominated and that women's football still faces challenges that impede or prevent 
[Type here]

progress. However, there are some contributions that account for the increasing number of female players and the improvements in women's football competitions (e.g. Hjelm and Olofsson, 2003; Hjelm, 2011), suggesting that as more women participate in football, matches become gradually more contested, balanced and exciting to watch (Araujo and Mießen, 2017; Pollard and Gómez, 2014). Importantly, attractiveness and competitiveness of the game are two characteristics that can drive demand for women's football (e.g. LeFeuvre, Stephenson and Walcott, 2013; Klein, 2009; Hallmann, 2012; Hallmann et al., 2016; Meier and Leinwather, 2012, Schallhorn, Knoll and Schramm, 2017), help stimulate interest from fans (see Andreff and Scelles, 2015; Scelles et al., 2013 for a review) and potentially lead to higher levels of media coverage and appeal to sponsors (Pfister, 2010). However, while these represent some of the principal issues that women's football stakeholders struggle to overcome, to date few publications in sport economics have empirically investigated the causality between factors that determined such developments in the women's game. Future studies in this area should critically evaluate the rather simplistic assumption that the low level of demand observed in women's football is due to the 'poor quality' of female players' technical performances. These debates should be reversed by referring to cases, such as Sweden and the US, where women's teams and female players have become popular and accepted (Hjelm, 2011; Hjelm and Olofsson, 2003). In addition, these examples should be utilised as baseline information to systematically answer questions about the improved levels of competitiveness in women's sports. As noted by Frick (2011), changes in women's sports competitiveness are not due to females' biological and psychological predispositions but to increasing prize money and improved socio-cultural conditions. Related to these aspects, articles (e.g. Brendtmann, Carsten and Otten, 2016; Jacobs, 2014) that tested for the importance of socio-economic factors in determining a country's international sporting success in women's football consistently found that gender equality is associated with better sporting performances. This would suggest that 
[Type here]

these countries are also more likely to invest in women's sports. However, available studies in women's football do not provide clear evidence to support this assumption.

Also, some articles (e.g. Bell and Blakey, 2010; Hellborg, 2013; Southall, Nagel and LeGrande, 2005) discussed where and how women's football is positioned and understood in the complex institutional environment of contemporary sports. In doing so, they have given attention to some of the issues that women's football stakeholders should recognise when it comes to selling women's football, a product that is influenced by a dual logic of 'business' and 'cause' (Allison, 2016). These publications described aspects of the game - including its contradictions - and proposed a number of critical questions on reasons that led to the failure of the first two attempts by women's football to break into the American professional sports market, specifically: Should these failures be interpreted as a backlash for equality? Is women's football not big enough to generate profitable business? What does the sport market stand for?

Understanding the positioning of women's football requires careful evaluations of how the sport may come to the fore across different sport cultures. In European countries, the percentage of girls that play football at a grassroots levels has certainly increased in the last three decades (UEFA, 2017). However, only in a few countries such as France, Sweden, Germany and England have leagues and matches started to gain considerable media attention and audiences. Thus, it is critical to consider that women's football is in a period of transition which inevitably presents divergent interests and contrasting forces. For instance, on the one hand, some national federations are trying to overhaul their leagues and turn them into full-time professional leagues (e.g. FA Women's Super League) in an attempt to cope with external pressures coming from social and political institutions. On the other hand, women's football clubs' owners and executives need to face challenges such as lack of financial profitability (European Club Association (ECA), 2014) and organisational difficulties (e.g. Aoki et al., 2010; Welford, 2013). 
[Type here]

Along with these, women's football researchers will need to engage in a number of critical issues that have emerged in women's football over the last 15 years. These include: the need for higher investment into the game (including shares of prize money at national and international tournaments), the necessity to modernise governance structures and uncertainty about players' career development, their working conditions (including policies for parental and childcare provisions) and their professional status (FIFPro, 2017a, 2017b, 2017c).

Based on this discussion, it is important that future research in women's football adopt crossdisciplinary approaches so as to:

- Increase the number of investigations regarding the positions of women in non-playing roles. These might provide additional insights on the challenges that women need to face in a men-dominated world;

- Focus research initiatives on cultures and countries that successfully challenged imbalanced gendered practices in (women's) football. These may offer explanations and insights about participant involvement and 'cultural appropriation' of the game;

- Identify, model and test the context- and sport-related factors that drive women's football development in terms of game attractiveness and competitiveness. This will enable researchers to develop theories on the evolution of the game from a sport economics perspective (see Berri, 2004; Szymanski, 2008, 2010 for a discussion) and help stakeholders evaluate key elements affecting the overall development of the game (e.g. participation rate, media coverage, financial investment), prioritise their actions and measure their outcomes in practice;

- Help understand the positioning of women's football in the professional sports market and evaluate the strategies undertaken by football leagues and clubs to sell the product and at the same time develop long-term sustainability; 
[Type here]

- Organise a unified framework that takes into account the existing divergent institutional logics and conflicting interests currently existing in the context of women's football in order to provide effective solutions to the abovementioned concerns; and

- Explore experiences of women (semi-)professional footballers with regards to their employment work-life issues as well the impact that welfare policies can have on their careers.

\section{Geographical location of research: is there a need to explore different countries and} cultures?

Research on women's football has been conducted around the globe considering more than 25 countries/areas. However, our results show that over three-quarters of women's football literature focussed on the same territories (e.g. Western Europe and the US). Importantly, those nations studied have never been ranked lower than $31^{\text {st }}$ (out of 177) in the FIFA/Coca-Cola World Women's ranking, meaning that research has concentrated on areas where women's football is already recognised and is to some extent developed.

Given the ambitions of international football authorities to develop the game worldwide and the important roles that cultural and socio-political context play in the development of women's football, we suggest that scholars consider broadening their research focus to include cultures and countries where less research has been conducted to date. For example, African, Asian and Latin American countries have been given comparatively less attention in the literature. In addition, nations where predominant cultures present lower levels of democracy and gender equality should be investigated more closely in order to enhance understanding of the societal attitudes that potentially lead to lower levels of women participation in football. This will help advance awareness about the impact that both culture and football policies have on women's 
[Type here]

football development and enable researchers and practitioners to ascertain factors that should be considered in designing initiatives to foster the growth of the game in different countries.

\section{Research methodology: how should we investigate women's football?}

This integrative review shows that women's football has been investigated primarily through qualitative research. This is to be expected given the prominence of sociological and historical studies which tend to adopt qualitative approaches such as interviews and document analysis. However, it is also important to underline that, in contrast to men's football where a plethora of statistics and quantitative measures is often publicly available, women's football research still relies on a relatively limited amount of quantitative data. A similar concern was expressed by Martinez-Lagunas, Niessen and Hartmann (2014) when reviewing contributions from sport science domains, a field where quantitative methods are commonly used.

Nevertheless, the emergence of new themes in economic and management disciplines contribute to the need to employ quantitative or mixed methods in women's football research. This is in line with the gradual process of expansion of women's football and the position it starts to occupy in the sports environment which might have led stakeholders to collect more measurable data in order to monitor and benchmark women's football. Therefore, based on this review, we argue that women's football literature will potentially shift its trend towards a more balanced distribution of qualitative and quantitative research outputs in the future. This interpretation is further reinforced by the release of official reports by FIFA in 2014 (e.g. The

FIFA Women's Football Survey) and UEFA since 2011 (e.g. Women's Football across National Associations) which include quantitative information about technical and managerial aspects of women's football in national member associations.

\section{An integrative review on women's football: final remarks}


[Type here]

This integrative review reveals that research on women's football has been increasing in the last two decades. However, it is worth noting that scholars from various academic disciplines have put considerable attention on this sport only in the last seven to ten years. Therefore, a number of research avenues still need to be explored, which in turn, will help interested parties understand how the sport can develop in the coming years.

We argue that historical and sociological research represents the foundations of women's football literature with social and cultural constraints such as gender discrimination and prejudices being identified as two of the principal problems when considering the experiences of women in football, both in playing and non-playing roles. This highlighting of broader societal concerns emphasises the need to consider issues such as power, ethics or institutional behaviour and governance when discussing - for instance - the allocation of resources to women's football by national governing bodies. Unquestionably, gender stereotypes still remain an issue within the football world. However, attitudes are gradually changing as women increasingly occupy more important positions in society and sport (Burton, 2015; Strittmatter and Skirstad, 2017; Welford, 2011). Importantly, Gammelsæter and Senaux (2011) put forward two critical questions related to this issue: 1) is the recent development of women's football a result of the general shift towards a more 'gender neutral' society? or, 2) is it an attempt by national governing bodies to extend their influence beyond men's football, presenting themselves as promoters of sport-for-all?

Higher gender equality in society, coupled with higher levels of democratisation, have been associated to greater levels of women's participation in sport (e.g. Balish, 2017). However, while international governing bodies have allocated larger amounts of resources to foster development of the sport in recent years, women's football still struggles to build a solid platform in terms of participation, professionalization and interest from fans, media and sponsors. Thus, additional questions arise: Do governing bodies provide equal opportunities to 
[Type here]

access and participate in the sport to both boys and girls? In more practical terms, does this increased allocation of resources to women's football reflect gender parity? Or should it be tailored differently to encourage higher levels of participation and enhance the overall development of the sport? In line with this, we believe that future research should discuss the interest in and support of women's football in different countries as well as identify, highlight and compare the situation of women's football with the development of other women's sports. Furthermore, we suggest that future studies take into account the evolution of women's football from managerial and business perspectives. Along with other lines of inquiry, it will be critical to pose a question as to whether women's football should seek to follow the path taken by men's football, that is to say, a path that has led to commercialisation (with the related issues that this can generate) (Kennedy and Kennedy, 2012; Morrow, 2017), or, instead, identify and follow a different path and business model reflective of the specifics of women's football. 
[Type here]

\section{References}

Allison, R. (2016), "Business or Cause? Gendered Institutional Logics in Women's Professional Soccer”, Journal of Sport and Social Issues, Vol. 40 No. 3, pp. 237-262.

Andreff, W. and Scelles, N. (2015), "Walter C. Neale 50 Years After: Beyond Competitive Balance, the League Standing Effect Tested With French Football Data", Journal of Sports Economics, Vol. 16 No. 8, pp. 819-834.

Aoki, K., Crumbach, S., Naicker, C., Schmitter, S. and Smith, N. (2010), "Identifying Best Practice in Women's Football: Case Study in the European Context". FIFA Master $10^{\text {th }}$ Edition, unpublished thesis, available at:

http://www.ciesuni.org/sites/default/files/identifying_best_practices_in_women_football.pdf (accessed 18 August 2016).

Araujo, M. C. and Mießen, K. A. M. (2017), “Twenty Years of the FIFA Women's World Cup: An Outstanding Evolution of Competitiveness", Women in Sport and Physical Activity Journal, Vol. 25 No. 1, pp. 60-64.

Balish, S. M. (2017), "Democracy predicts sport and recreation membership: Insights from 52 countries", Journal of Epidemiology and Global Health, Vol. 7 No. 1, pp. 21-28

Bell, B. and Blakey P. (2010), "Do Boys and Girls Go Out To Play? Women's Football and Social Marketing at EURO 2005”, International Journal of Sport Management and Marketing, Vol. 7 No. 34, pp. 156-172.

Ben-Porat, A. (2009), "Not Just for Men: Israeli Women Who Fancy Football”, Soccer \& Society, Vol. 10 No. 6, pp. 883-896.

Berri, D. J. (2004), “Is There a Short Supply of Tall People in the College Game?”, In Fizel, J. and Fort R. (Ed.), Economics of College Sports, Praeger Publishers, Westport, CT, pp. 211-223.

Botelho, V. L. and Agergaard, S. (2011), "Moving for the Love of the Game? International Migration of Female Footballers into Scandinavian countries", Soccer \& Society, Vol. 12 No. 6, pp. 806-819. 
[Type here]

Bourke, A. (2003), "Women's Football in the Republic of Ireland: Past Events and Future Prospects". Soccer \& Society, Vol. 4 No. 2-3, pp. 162-181.

Burton, L. J. (2015), "Underrepresentation of Women in Sport Leadership: A Review of Research", Sport Management Review, Vol. 18 No. 2, pp. 155-165.

Brendtmann, J., Carsten, J. C. and Otten, S. (2016), “The Effect of Gender Equality on International Soccer Performance”, International Journal of Sport Finance, Vol. 11 No. 4, pp. 288-309.

Caudwell, J. (1999), “Women's Football in the United Kingdom Theorizing Gender and Unpacking the Butch Lesbian Image”, Journal of Sport and Social Issues, Vol. 23 No. 4, pp. 390-402.

Caudwell, J. (2003), "Sporting Gender: Women's Footballing Bodies as Sites/Sights for the (Re) Articulation of Sex, Gender, and Desire", Sociology of Sport Journal, Vol. 20 No. 4, pp. 371-386.

Caudwell, J. (2011), “Gender, Feminism and Football Studies”, Soccer \& Society, Vol. 12 No. 3, pp. $330-344$.

Christopherson, N., Janning M. and McConnell, E. D. (2002), “Two Kicks Forward, One Kick Back: A Content Analysis of Media Discourses on the 1999 Women's World Cup Soccer Championship", Sociology of Sport Journal, Vol. 19 No. 2, pp. 170-188.

Coche, R. (2016), "Promoting Women's Soccer through Social Media: How the US Federation used Twitter for the 2011 World Cup", Soccer \& Society, Vol. 17 No. 1, pp. 90-108.

Cooper, H. M. (1989), Integrating research: A guide for literature reviews, Sage Publications: Newbury Park.

Dunn, C. (2016), “Elite Footballers as Role Models: Promoting Young Women's Football Participation", Soccer \& Society, Vol. 17 No. 6, pp. 843-855.

Dunn, C. (2017), “The Impact of the Supporters Trust Movement on Women's Feelings and Practices of their Football Fandom", Soccer \& Society, Vol. 4 No. 4, pp. 462-475. 
[Type here]

ECA (2014), “European Clubs’ Association - Women's Football Committee - Women's Club Football Analysis"

(Report),

available

at

http://www.ecaeurope.com/PageFiles/7585/ECA Womens\%20Club\%20Football\%20Analysis double \%20pages.pdf (accessed 22 November 2016).

Fasting, K. and Pfister, G. (2000), "Female and Male Coaches in the Eyes of Female Elite Soccer players", European Physical Education Review, Vol. 6 No. 1, pp. 91-110.

Fasting, K. (2003), “Small Country-Big Results: Women's football in Norway”, Soccer \& Society, Vol. 4 No. 2-3, pp. 149-161.

Fasting, K, Sand, T. S. and Nordstrand, H. R. (2017), "One of the Few: The Experiences of Female Elite-level Coaches in Norwegian Football", Soccer \& Society. Published online DOI: $10.1080 / 14660970.2017 .1331163$

Fielding-Lloyd, B. and Meân L. J. (2008), "Standards and Separatism: The Discursive Construction of Gender in English Soccer Coach Education”, Sex Roles, Vol. 58 No. 1-2, pp. 24-39.

FIFA (2014), "The Women`s Survey", available at: http://www.fifa.com/mm/document/footballdevelopment/women/02/52/26/49/womensfootballsurvey2

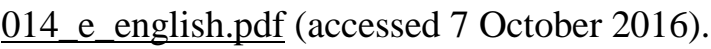

FIFA (2016), "FIFA 2.0: The Vision for the Future", available at: https://www.sportanddev.org/sites/default/files/downloads/fifa 2.0. the vision for the future.pdf (accessed 22 November 2016).

FIFPro (2017a), “2017 FIFPro Global Employment Report: Working Conditions in Professional Women's Football", available at: https://www.fifpro.org/attachments/article/6986/2017\%20FIFPro\%20Women\%20Football\%20Global \%20Employment\%20Report-Final.pdf (accessed 15 December 2017).

FIFPro (2017b), “Norway’s Equal Pay Deal Explained”, available at: https://www.fifpro.org/news/whos-next-explaining-the-norwegian-football-pay-deal/en/ (accessed 11 October 2017) 
[Type here]

FIFPro (2017c), “Danish Women's World Cup Conflict Explained”, available at:

https://www.fifpro.org/news/danish-women-s-world-cup-conflict-explained/en/ (accessed 19

September 2017).

Frick, B. (2011), “Gender Differences in Competitiveness: Empirical Evidence from Professional

Distance Running”, Labour Economics, Vol. 18 No.3, pp. 389-398.

Gammelsæter, H. and Senaux, B. (2011), “Understanding the Governance of Football Across

Europe", in Gammelsæter, H. and Senaux, B., The Organisation and Governance of Top Football

Across Europe. An Institutional Perspective, Routledge: New York, pp. 268-291.

Hallmann, K. (2012). "Women's 2011 Football World Cup: The Impact of Perceived Images of Women's Soccer and the World Cup 2011 on Interest in Attending Matches", Sport Management Review, Vol. 15 No. 1, pp. 33-42.

Hallmann, K., Oshimi, D., Harada, M., Matsuoka, H. and Breuer, C. (2016), "Spectators' Point of Attachment and Their Influence on Behavioural Intentions of Women's National Football Games", Soccer \& Society, p. 1-21. doi: 10.1080/14660970.2016.1267634

Hellborg, A. M. (2013), “The Challenges of Sustaining a Professional Soccer League for Women”, paper presented at Football Research in an Enlarged Europe (FREE) conference, June, University of Copenhagen (Denmark), available at: http://www.free-project.eu/documentsfree/Working $\% 20$ Papers/Hellborg $\% 20$ The $\% 20$ challenges $\% 20 \mathrm{of} \% 20$ sustaining $\% 20 \mathrm{a} \% 20$ professional \%20soccer\%20league\%20for\%20women.pdf (accessed 14 September 2016).

Hjelm, J. and Olofsson E. (2003), “A Breakthrough: Women's Football in Sweden”, Soccer \& Society, Vol. 4 No. 2-3, pp. 182-204.

Hjelm, J. (2011), “The Bad Female Football Player: Women's Football in Sweden”, Soccer \& Society, Vol. 12 No. 2, pp. 143-158. 
[Type here]

Hjelseth, A. and Hovden, J. (2014), "Negotiating the Status of Women's Football in Norway. An Analysis of Online Supporter Discourse”, European Journal for Sport and Society, Vol. 11 No. 3, pp. 253-277.

Jacobs, J. C. (2014), "Programme-level Determinants of Women`s International Football Performance", European Sport Management Quarterly, Vol. 14 No. 5, pp. 521-537.

Kennedy, P. and Kennedy, D. (2012), "Football Supporters and the Commercialisation of Football: Comparative Responses across Europe”, Soccer \& Society, Vol. 13 No. 3, pp. 327-340.

Kim, H-M. (2004), “Feminization of the 2002 World Cup and Women's Fandom”, Inter-Asia Cultural Studies, Vol. 5 No. 1, pp. 42-51.

Kim, M-C. and Hong, E. (2016), "A Red Card for Women: Female Officials ostracized in South Korean Football”, Asian Journal of Women's Studies, Vol. 22 No. 2, pp. 114-130.

Kjær, J. B. and Agergaard, S. (2013), "Understanding Women`s Professional Soccer: the Case of Denmark and Sweden”, Soccer \& Society, Vol. 14 No. 6, pp. 816-833.

Klein, M. W. (2004), "Work and Play: International Evidence of Gender Equality in Employment and Sports", Journal of Sports Economics, Vol. 5 No. 3, pp. 227-242.

Klein, M-L. (2009), “Spectator Demand for Women's Football in Germany”, paper presented at $17^{\text {th }}$ European Association for Sport Management (EASM) Conference, September 16-19, Amsterdam,

Netherlands, $\quad$ available $\quad$ at http://www.easm.net/download/2009/f548e401f887b14281f25dcc1843e781.pdf $\quad$ (accessed 30 November 2016).

Knoppers, A. and Anthonissen, A. (2003), "Women's Soccer in the United States and the Netherlands: Differences and Similarities in Regimes of Inequalities", Sociology of Sport Journal, Vol. 20 No. 4, pp. $351-370$ 
[Type here]

LeFeuvre, A. D., Stephenson, F. E. and Walcott, S. M. (2013), "Football Frenzy: The Effect of the 2011 World Cup on Women's Professional Soccer League Attendance”, Journal of Sports Economics, Vol. 14 No. 4, pp. 440-448.

Lewis, R. (2009), “ 'Our Lady Specialists at Pikes Lane': Female Spectators in Early English Professional Football", The International Journal of the History of Sport, Vol. 26 No. 15, pp. 21612181.

Lewis, C. J., Roberts, S. J and Andrews, H. (2015), “ 'Why am I putting myself through this?' Women Football Coaches' Experiences of the Football Association's Coach Education Process", Sport, Education and Society, pp. 1-12.

Macbeth, J. (2002), “The Development of Women's Football in Scotland”, Sports Historian, Vol. 22 No. 2, pp. 149-163.

Martinez-Lagunas, V., Niessen, M. and Hartmann, U. (2014), "Women's Football: Player Characteristics and Demands of the Game", Journal of Sport and Health Sciences, Vol. 3 No. 4, pp. $258-272$

Meier, H. E., Konjer, M. and Leinwather, M. (2016), “The Demand for Women`s League Soccer in Germany", European Sport Management Quarterly, Vol. 16 No. 1, pp. 1-19.

Meier, H. E. and Leinwather, M. (2012), “Women as 'Armchair Audience'? Evidence from German National Team Football”, Sociology of Sport Journal, Vol. 29 No. 3, pp. 365-384.

Melkersson, M. (2013), "Brand Management as a Vantage Point for Revisiting Developmental Opportunities and Challenges within Contemporary Women's Soccer in Sweden: the Case of LdB FC Malmö”, Soccer \& Society, Vol. 14 No. 6, pp. 834-849.

Miles, M. B. and Huberman, A. M. (1994), Qualitative data analysis: An expanded sourcebook. Thousand Oaks: Sage.

Mintert, S-M. and Pfister, G. (2015), "The FREE project and the Feminization of Football: The Role of Women in the European Fan Community”, Soccer and Society, Vol. 16 No. 2-3, pp. 405-421. 
[Type here]

Morrow, S. (2017), “Football, Economics and Finance”, in Hughson, J., Moore, K., Spaaij, R., Maguire, J., Routledge Handbook of Football Studies, Routledge, New York, pp. 163-176.

Norman, L. (2014), “A Crisis of Confidence: Women Coaches' Responses to Their Engagement in Resistance", Sport, Education and Society, Vol. 19 No. 5, pp. 532-551.

O’Mathúna, D. P., (2000), “Evidence-based Practice and Reviews of Therapeutic Touch”, Journal of Nursing Scholarship, Vol. 32 No. 3, pp. 279-285.

Peeters, R. and Elling, A. (2015), “The Coming of Age of Women's Football in the Dutch Sports Media, 1995-2013”, Soccer \& Society, Vol. 16 No. 5-6, pp. 620-638.

Peeters, R. and van Sterkenburg, J. (2017), "Making Sense of Race/Ethnicity and Gender in Televised Football: Reception Research among British Students”, Sport in Society, Vol. 20 No. 5-6, pp. 1-15.

Perreau-Niel, A. and Erard, C. (2015), "French Football Referees: An Exploratory Study of the Conditions of Access and Employment for Referees in Terms of Level and Gender", Soccer \& Society, Vol. 16 No. 1, pp. 1-16

Pfister, G., Fasting, K., Scraton, S. and Vazquez, B. (1999), "Women and Football - A Contradiction? The Beginnings of Women's Football in Four European Countries", The European Sports History Review, Vol. 1, pp. 1-26.

Pfister, G., Lenneis, V. and Mintert, S. (2013), "Female Fans of Men's Football - A Case Study in Denmark", Soccer \& Society, Vol. 14 No. 6, pp. 850-871.

Pfister, G. (2010), "Women in Sport: Gender Relations and Future Perspectives", Sport in Society: Culture, Commerce, Media, Politics, Vol. 13 No. 2, pp. 234-248.

Pfister, G. (2013), "Women, Football and European Integration: Aims and Questions, Methodological and Theoretical Approaches", Annales Kinesiologiae, Vol. 4 No. 1, pp. 29-43.

Pfister, G. (2015a), “Assessing the Sociology of Sport: On Women and Football”, International Review for the Sociology of Sport, Vol. 50 No. 4-5, pp. 563-569. 
[Type here]

Pfister, G. (2015b), "Sportswomen in the German Popular Press: A Study Carried Out in the Context of the 2011 Women's Football World Cup", Soccer \& Society, Vol. 16 No. 5-6, pp. 639-656.

Pollard, R. and Gòmez, M. A. (2014), “Comparison of Home Advantage in Men's and Women's Football Leagues in Europe”, European Journal of Sport Science, Vol. 14 No. 1, pp. S77-S83.

Pope, S. (2012), “'The Love of My Life': The Meaning and Importance of Sport for Female Fans”, Journal of Sport and Social Issues, Vol. 12 No. 6, pp. 176-195.

Pope, S. (2014), “'There are Some Daft People Out There!': Exploring Female Sport and Media Fandoms", Sport in Society, Vol. 17 No. 2, pp. 254-269.

Pope, S. (2015), “ “It’s Just Such a Class Thing': Rivalry and Class Distinction Between Female Fans of Men's Football and Rugby Union”, Sociological Research Online, Vol. 20 No. 1, pp. 1-14.

Pope, S. (2016), "Female Fan Experiences and Interpretations of the 1958 Munich Air Disaster, the 1966 World Cup Finals and the Rise of Footballers as Sexualised National Celebrities”, International Review for the Sociology of Sport, Vol. 51 No. 7, pp. 848-866.

Pope, S. and Williams, J. (2011), “ ‘White Shoes to a Football Match!': Female Experiences of Football's Golden Age in England", Transformative Works and Cultures, No. 6. Published online DOI: 10.3983/twc.2011.0230.

Rothbauer, P. M. (2008), “Triangulation”, in Given, L. M. (Ed.), The SAGE Encyclopedia of Qualitative Research Methods, SAGE Publications: Thousands Oaks, pp. 893-894.

Scelles, N., Durand, C., Bonnal, L., Goyeau, D. and Andreff, W. (2013), "Competitive Balance versus Competitive Intensity Before a Match: Is One of These Two Concepts More Relevant in Explaining Attendance? The Case of the French football Ligue 1 Over the Period 2008-2011”, Applied Economics, Vol. 45 No. 29, pp. 4184-4192.

Schallhorn, C., Knoll, J. and Schramm, H. (2017), “'Girls Just Want to Have Fun?' Sex Differences in Motives of Watching the FIFA World Cup and the UEFA European Championship", Sport in Society, Vol. 20 No. 9, pp. 1118-1133. 
[Type here]

Schlesinger, T. and Weigelt-Schlesinger, Y. (2012), “ 'Poor thing' or 'Wow, She Knows How to Do It'-Gender Stereotypes as Barriers to Women's Qualification in the Education of Soccer Coaches", Soccer \& Society, Vol. 13 No. 1, pp. 56-72.

Schulenkorf, N., Sherry, E. and Rowe, K. (2016), "Sport for Development: An Integrated Literature Review", Journal of Sport Management, Vol. 30 No. 1, pp. 22-39.

Scraton, S., Caudwell, J. and Holland, S. (2005), “ 'Bend It Like Patel: Centring 'Race', Ethnicity and Gender in Feminist Analysis of Women's Football in England”, International Review for the Sociology of Sport, Vol. 40 No. 1, pp. 71-88.

Selmer, N. and Sülzle, A. (2010), "(En-)Gendering the European Football Family: The Changing Discourse on Women and Gender at EURO 2008”, Soccer \& Society, Vol. 11 No. 6, pp. 803-814.

Skogvang, B. O and Fasting, K. (2013), "Football and Sexualities in Norway", Soccer \& Society, Vol. 14 No. 6, pp. 872-886.

Skogvang, B. O. (2009), “The Sport/Media Complex in Norwegian Football”, Soccer \& Society, Vol. 10 No. 3-4, pp. 438-458.

Southall, R. M., Nagel, M. S. and LeGrande, D. J. (2005), “Build It and They Will Come? The Women's United Soccer Association: A Collision of Exchange Theory and Strategic Philanthropy", Sport Marketing Quarterly, Vol. 14 No. 3, pp. 158-167.

Strittmatter, A-M. and Skirstad, B. (2017), “Managing Football Organizations: A Man's World? Comparing Women in Decision-making Positions in Germany and Norway and Their International Influence: A Contextual Approach”, Soccer \& Society, Vol. 18 No. 1, pp. 81-101.

Szymanski, S. (2008), “A Theory of the Evolution of Modern Sport”, Journal of Sport History, Vol. 35 No. 1, pp. 1-32.

Szymanski, S. (2010), "Income Inequality, Competitive Balance and the Attractiveness of Team Sports: Some Evidence and a Natural Experiment from English Soccer”, in Szymanski, S., Football Economics and Policy, Palgrave Macmilann, London, pp. 182-201. 
[Type here]

Tavares de Souza, M., Dias da Silva, M. and de Carvalho, R. (2010), "Integrative review: What is it? How to do it?", Einstein (Sao Paulo), Vol. 8 No. 1, pp. 102-106.

Tiesler, N. C. (2016), “Three Types of Transnational Players: Differing Women's Football Mobility Projects in Core and Developing Countries", Revista Brasileira de Ciências do Esporte, Vol. 38 No. 2, pp. 201-210.

Torgler, B. (2008), “The Determinants of Women's International Soccer Performances”, International Journal of Sport Management and Marketing, Vol. 3 No. 4, pp. 305-318.

Torraco, R. J. (2005), "Writing Integrative Literature Reviews: Guidelines and Examples", Human Resource Development Review, Vol. 4 No. 3, pp. 356-367.

UEFA (2016), "Women`s Football across the National Associations 2015-2016", available at: http://www.uefa.org/MultimediaFiles/Download/OfficialDocument/uefaorg/Women'sfootball/02/30/9 3/30/2309330 DOWNLOAD.pdf (accessed 7 October 2016).

UEFA (2017), “Women's Football across the National Associations 2016-2017", available at: https://www.uefa.com/MultimediaFiles/Download/OfficialDocument/uefaorg/Women'sfootball/02/43/ 13/56/2431356_DOWNLOAD.pdf (accessed 15 November 2017)

Welford, J. (2011), “Tokenism, Ties and Talking Too Quietly: Women`s Experiences in Non-playing Football Roles”, Soccer \& Society, Vol. 12 No. 3, pp. 365-381.

Welford, J. (2013), "Outsiders on the Inside: Integrating Female and Male Football Clubs in the UK", paper presented at Football Research in an Enlarged Europe (FREE) conference, June, University of Copenhagen (Denmark).

Whittemore, R. and Knafl, K. (2005), “The Integrative Review: Updated Methodology”, Journal of Advanced Nursing, Vol. 52 No. 5, pp. 546-553.

Williams, J. and Hess, R. (2015), "Women, Football and History: International Perspectives", The International Journal of the History of Sport, Vol. 32 No. 18, pp. 2115-2122. 
[Type here]

Table 1 - Explanation of how themes emerged

\begin{tabular}{|l|l|l|}
\hline Category & Description & Example \\
\hline Subject area & $\begin{array}{l}\text { The broad discipline in which the article can be } \\
\text { allocated. It reflects the question that scholars } \\
\text { tried to answer in their paper. }\end{array}$ & Economics \\
\hline Topics & $\begin{array}{l}\text { The problem within the subject area that authors } \\
\text { attempted to direct. }\end{array}$ & Economics $\rightarrow$ Success \\
\hline Actors/levels & $\begin{array}{l}\text { The physical or abstract main focus of the article } \\
\text { which is expected to either directly answer the } \\
\text { question or inform the author about their research } \\
\text { enquiry. }\end{array}$ & Economics $\rightarrow$ Success $\rightarrow$ Country \\
\hline
\end{tabular}


[Type here]

Table 2 - Organisation, definition and examples of articles according to subject, topic and level

\begin{tabular}{|c|c|c|c|c|c|}
\hline Subject & Topic & Level & $\mathbf{n}$ & Definition & Reference \\
\hline \multirow[t]{5}{*}{ Economics } & Attractiveness & Players & 1 & $\begin{array}{l}\text { The evaluation of factors } \\
\text { (e.g. game quality) related } \\
\text { to the ability of women's } \\
\text { football to attract } \\
\text { spectators, media coverage } \\
\text { and sponsors }\end{array}$ & Hjelm (2011) \\
\hline & \multirow[t]{2}{*}{ Competitiveness } & Federation & 1 & \multirow[b]{2}{*}{$\begin{array}{l}\text { The analysis of factors (e.g. } \\
\text { home advantage effect, } \\
\text { competitive balance) } \\
\text { related to competition } \\
\text { fairness in women's } \\
\text { football }\end{array}$} & \multirow{2}{*}{$\begin{array}{l}\text { Pollard and Gomez- } \\
\text { Ruano (2014) }\end{array}$} \\
\hline & & League & 1 & & \\
\hline & Consumption & Fandom & 3 & $\begin{array}{l}\text { The study of the economic } \\
\text { determinants associated } \\
\text { with the consumption of } \\
\text { women's football games }\end{array}$ & $\begin{array}{l}\text { LeFeuvre, } \\
\text { Stephenson and } \\
\text { Walcott (2013) }\end{array}$ \\
\hline & Success & Country & 7 & $\begin{array}{l}\text { The study of socio- } \\
\text { economic determinants } \\
\text { associated with sporting } \\
\text { success in women's } \\
\text { football }\end{array}$ & Torgler (2008) \\
\hline \multirow[t]{3}{*}{ Historical } & \multirow[t]{3}{*}{ Evolution } & Country & 26 & \multirow{3}{*}{$\begin{array}{l}\text { The analysis of socio- } \\
\text { political and historical } \\
\text { events that have influenced } \\
\text { the development of } \\
\text { women's football and its } \\
\text { stakeholders }\end{array}$} & \multirow[t]{3}{*}{ Bourke (2003) } \\
\hline & & Fandom & 2 & & \\
\hline & & Players & 1 & & \\
\hline \multirow[t]{2}{*}{ Management } & Organisation & Club & 2 & $\begin{array}{l}\text { The study of organisations' } \\
\text { actions and strategies } \\
\text { operating within women's } \\
\text { football }\end{array}$ & Aoki et al. (2010) \\
\hline & Policy & Federation & 3 & $\begin{array}{l}\text { The evaluation of plans, } \\
\text { initiatives and } \\
\text { opportunities intended to } \\
\text { influence and improve } \\
\text { women's football }\end{array}$ & $\begin{array}{l}\text { Kjær and Agergaard } \\
(2013)\end{array}$ \\
\hline \multirow[t]{4}{*}{ Marketing } & Branding & Club & 1 & The study of brand & Melkersson (2013) \\
\hline & & League & 1 & $\begin{array}{l}\text { management in women's } \\
\text { football }\end{array}$ & \\
\hline & Consumption & Fandom & 5 & $\begin{array}{l}\text { The identification of } \\
\text { drivers and demographics } \\
\text { associated with } \\
\text { consumption of women's } \\
\text { football games }\end{array}$ & Hallmann (2012) \\
\hline & Strategy & $\begin{array}{l}\text { Federation } \\
\text { League }\end{array}$ & $\begin{array}{l}1 \\
3\end{array}$ & $\begin{array}{l}\text { The analysis and } \\
\text { evaluation of the marketing } \\
\text { strategies used to promote } \\
\text { women's football }\end{array}$ & $\begin{array}{l}\text { Southall, Nagel and } \\
\text { LeGrande (2005) }\end{array}$ \\
\hline
\end{tabular}


[Type here]

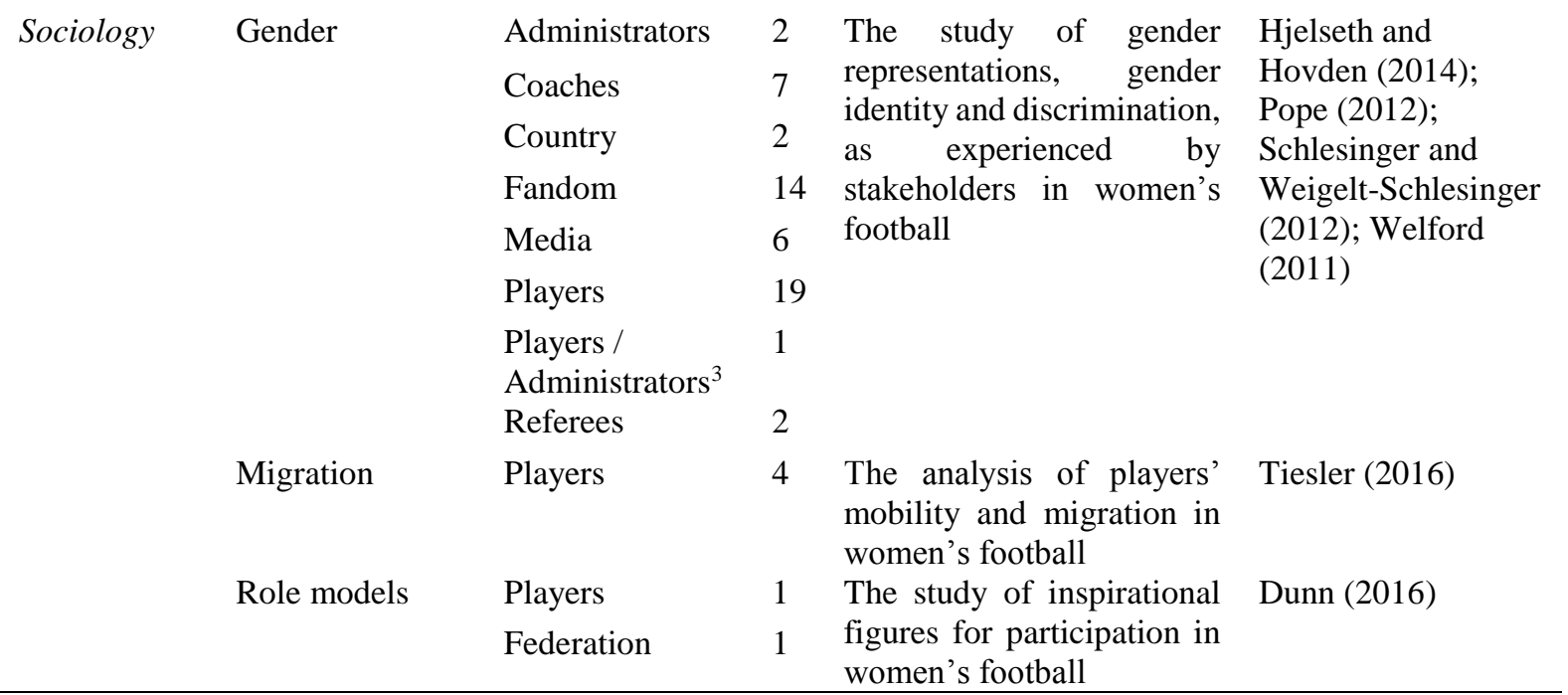

${ }^{3}$ It is challenging to extract the fundamental actor/level in Scraton, Caudwell and Holland (2005) as they clearly state that interviews were conducted with seven players and seven administrators. 
[Type here] 
[Type here]

Table 3 - Publications' distribution over time

\begin{tabular}{|c|c|c|c|c|c|c|c|c|c|c|c|c|c|c|c|c|c|c|c|c|c|c|c|}
\hline & & & 1998 & 1999 & 2000 & 2001 & 2002 & 2003 & 2004 & 2005 & 2006 & 2007 & 2008 & 2009 & 2010 & 2011 & 2012 & 2013 & 2014 & 2015 & 2016 & 2017 & Total \\
\hline \multirow{5}{*}{ Economics } & Attractiveness & Players & & & & & & & & & & & & & & 1 & & & & & & & 1 \\
\hline & Competitiveness & Federation & & & & & & & & & & & & & & & & & & & & 1 & 1 \\
\hline & & League & & & & & & & & & & & & & & & & & 1 & & & & 1 \\
\hline & Consumption & Fandom & & & & & & & & & & & & & & & 1 & 1 & & & 1 & & 3 \\
\hline & Success & Country & & & & & & & 1 & & 1 & & 1 & & & 1 & & 1 & 1 & & 1 & & 7 \\
\hline \multirow[t]{3}{*}{ History } & Evolution & Country & 1 & 1 & & 1 & 1 & 15 & & & 1 & & & & 1 & & 2 & & 1 & 1 & & 1 & 26 \\
\hline & & Fandom & & & & & & & & & & & & 1 & & & & & 1 & & & & 2 \\
\hline & & Players & & & & & & & & & & & & & & 1 & & & & & & & 1 \\
\hline \multirow[t]{2}{*}{ Management } & Organisation & Club & & & & & & & & & & & & & 1 & & & 1 & & & & & 2 \\
\hline & Policy & Federation & & & & & & & & & & & & & & & 1 & 2 & & & & & 3 \\
\hline \multirow[t]{5}{*}{ Marketing } & Branding & Club & & & & & & & & & & & & & & & & 1 & & & & & 1 \\
\hline & & League & & & & & & & & & & & & & & & & & & & 1 & & 1 \\
\hline & Consumption & Fandom & & & & & & & & & & & & 1 & & & 1 & 1 & & & 1 & 1 & 5 \\
\hline & Strategy & Federation & & & & & & & & & & & & & 1 & & & & & & & & 1 \\
\hline & & League & & & & & & & & 1 & & & & & & & & 1 & & & 1 & & 3 \\
\hline \multirow[t]{11}{*}{ Sociology } & Gender & Administrators & & & & & & & & & & & & & & 1 & & & & & & 1 & 2 \\
\hline & & Coaches & & & 1 & & & & & & & & 1 & & & & 1 & 1 & 1 & 1 & & 1 & 7 \\
\hline & & Country & & & & & & 1 & & & & & & & & & & 1 & & & & & 2 \\
\hline & & Fandom & & & & & & & 1 & & & & & 1 & 1 & 1 & 1 & 2 & 2 & 2 & 1 & 2 & 14 \\
\hline & & Media & & & & & 1 & & & & & & & 1 & & & & & & 2 & 1 & 1 & 6 \\
\hline & & Players & & 2 & & & & 1 & & 2 & 1 & & 1 & & & 6 & & 1 & 1 & 2 & 1 & 1 & 19 \\
\hline & & $\begin{array}{l}\text { Players / } \\
\text { Administrators }\end{array}$ & & & & & & & & 1 & & & & & & & & & & & & & 1 \\
\hline & & Referees & & & & & & & & & & & & & & & & & & 1 & 1 & & 2 \\
\hline & Migration & Players & & & & & & & & & & & & & & 1 & & 2 & & & 1 & & 4 \\
\hline & Role models & Federation & & & & & & & & & & & & & & & & & & & 1 & & 1 \\
\hline & & Players & & & & & & & & & & & & & & & & & & & 1 & & 1 \\
\hline Total & & & 1 & 3 & 1 & 1 & 2 & 17 & 2 & 4 & 3 & 0 & 3 & 4 & 4 & 12 & 7 & 15 & 8 & 9 & 12 & 9 & \\
\hline
\end{tabular}


[Type here] 
[Type here]

Table 4 - Themes with more than three publications

\begin{tabular}{llll}
\hline & & & Total \\
\hline Economics & Success & Country & 7 \\
History & Evolution & Country & 26 \\
Marketing & Consumption & Fandom & 5 \\
Sociology & Gender & Coaches & 7 \\
& & Fandom & 14 \\
& & Media & 6 \\
& & Players & 19 \\
& Migration & Players & 4 \\
\hline Total & & & 88 \\
\hline
\end{tabular}

Table 5 - The first five outlets by number of published articles

\begin{tabular}{ll}
\hline Publication outlet & Frequency \\
\hline Soccer \& Society & 49 \\
International Review for the Sociology of Sport & 6 \\
Sport in Society & 6 \\
Journal of Sport and Social Issues & 5 \\
The International Journal of the History of Sport & 5 \\
\hline
\end{tabular}


[Type here]

Table 6 - Publications' distribution over geographical contexts where three or more studies were conducted

\begin{tabular}{|c|c|c|c|c|c|c|c|c|c|c|c|c|c|c|c|}
\hline & & & Denmark & England & Europe & Germany & International & Korea S. & Norway & Scandinavia & Scotland & Sweden & UK & US & Total \\
\hline \multirow{5}{*}{ Economics } & Attractiveness & Players & & & & & & & & & & 1 & & & 1 \\
\hline & Competitiveness & Federation & & & & & 1 & & & & & & & & 1 \\
\hline & & Leagues & & & 1 & & & & & & & & & & 1 \\
\hline & Consumption & Fandom & & & & 2 & & & & & & & & 1 & 3 \\
\hline & Success & Country & & & & & 7 & & & & & & & & 7 \\
\hline \multirow[t]{3}{*}{ History } & Evolution & Country & 1 & 2 & 1 & 2 & 1 & 1 & 1 & & 1 & 1 & & 2 & 13 \\
\hline & & Fandom & 1 & 1 & & & & & & & & & & & 2 \\
\hline & & Players & & & 1 & & & & & & & & & & 1 \\
\hline \multirow[t]{2}{*}{ Management } & Organisation & Club & & 1 & 1 & & & & & & & & & & 2 \\
\hline & Policy & Federation & & 1 & & & & & & & & & & & 1 \\
\hline \multirow[t]{5}{*}{ Marketing } & Branding & Club & & & & & & & & & & 1 & & & 1 \\
\hline & & League & 1 & & & & & & & & & & & & 1 \\
\hline & Consumption & Fandom & & & & 2 & & & & & & & & 1 & 3 \\
\hline & Strategy & Federation & & 1 & & & & & & & & & & & 1 \\
\hline & & League & & & & & & & & & & & & 3 & 3 \\
\hline \multirow[t]{11}{*}{ Sociology } & Gender & Administrators & & & & & & & & & & & 1 & & 1 \\
\hline & & Coaches & & 2 & & 1 & & & 2 & & & & 1 & & 6 \\
\hline & & Country & & & & & 1 & & & & & & & & 1 \\
\hline & & Fandom & 1 & 4 & 3 & & & 1 & 1 & & & & 2 & 1 & 13 \\
\hline & & Media & & & & 1 & & & 1 & & & & 1 & 2 & 5 \\
\hline & & Players & & 3 & 2 & & 2 & & & & 2 & & 5 & 2 & 16 \\
\hline & & $\begin{array}{l}\text { Players / } \\
\text { Administrators }\end{array}$ & & 1 & & & & & & & & & & & 1 \\
\hline & & Referees & & & & & & 1 & & & & & & & 1 \\
\hline & Migration & Players & & & & & & & & 3 & & & & & 3 \\
\hline & Role models & Federation & & & & 1 & & & & & & & & & 1 \\
\hline & & Players & & & & & & & & & & & 1 & & 1 \\
\hline Total & & & 4 & 16 & 9 & 9 & 12 & 3 & 5 & 3 & 3 & 3 & 11 & 12 & \\
\hline
\end{tabular}


[Type here] 
[Type here]

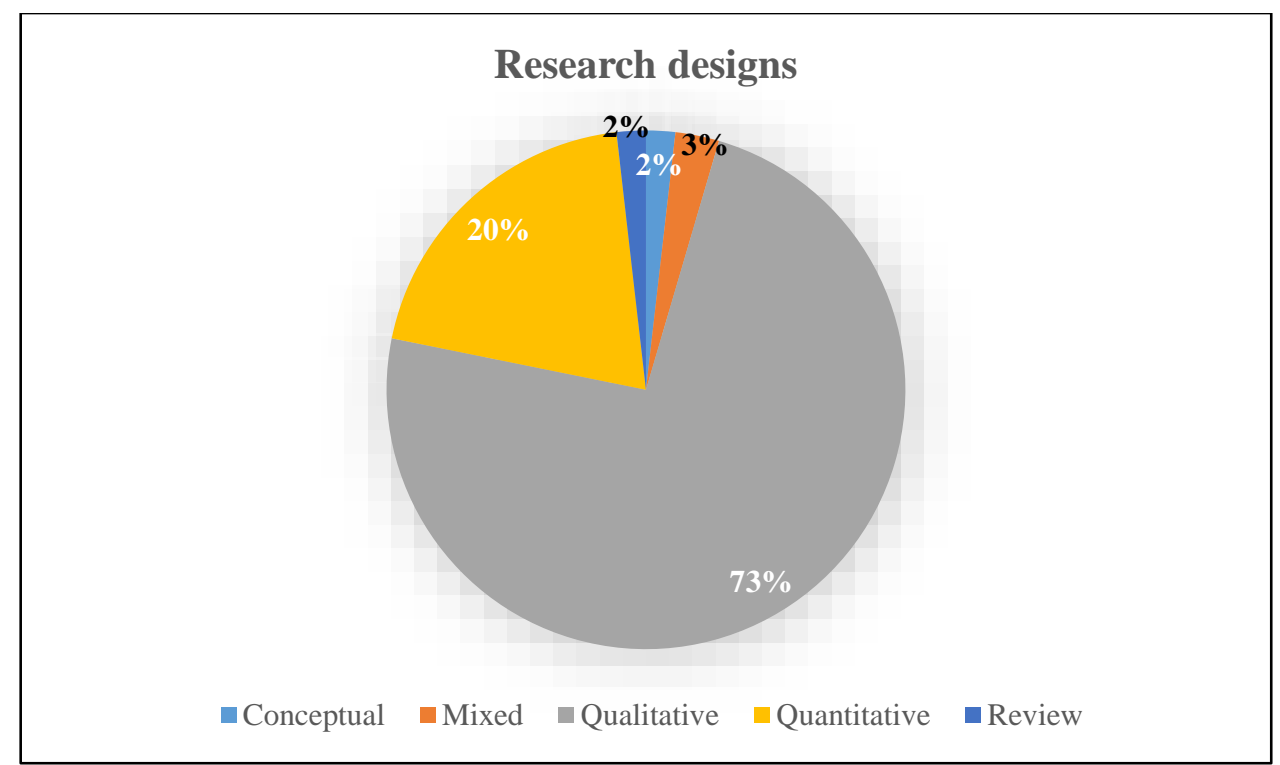

Figure 1 - Research designs utilised to study women's football 